\title{
PENGARUH PEMANFAATAN MEDIA E-LEARNING DAN KEMANDIRIAN BELAJAR TERHADAP KREATIVITAS MAHASISWA PADA MATA KULIAH ANALISA LAPORAN KEUANGAN FKIP EKONOMI ANGKATAN 2017 UNIVERSITAS HKBP NOMMENSEN TAHUN AJARAN 2020/2021
}

\author{
Juliper Nainggolan", Marisi Hutasoit ${ }^{2}$ \\ Fakultas Keguruan dan Ilmu Kependidikan, Universitas HKBP Nommensen \\ julifer_n@yahoo.com
}

\begin{abstract}
ABSTRAK: Penelitian ini bertujuan untuk mengetahui pengaruh pemanfaatan media e-learning dan kemandirian belajar terhadap kreativitas mahasiswa pada mata kuliah analisa laporan keuangan Fkip Ekonomi angkatan 20017 Universitas HKBP Nommensen Tahun Ajaran 2020/2021. Penelitian ini dilakukan di Universitas HKBP Nommensen Medan FKIP Ekonomi. Hasil penelitian ini menunjukkan bahwa pemanfaatan e-learning dalam pembelajaran sangat membantu mahasiswa/peserta didik untuk meningkatkan aktivitas belajar, kejujuran dan memiliki kepribadian yang mandiri. Fenomena yang terjadi juga menggambarkan selama pandemic covid-19 meningkatkan kemandirian belajarnya. Pemanfaatan media e-learning dan kemadirian belajar berpengaruh positif terhadap kreativitas mahasiswa dalam matakuliah analisa laporan keuangan program studi pendidikan ekonomi tahun ajaran 2020/2021 dengan persamaan $\mathrm{Y}=10,061+0,433 \mathrm{X}_{1}+$ $0,461 \mathrm{X}_{2}$.
\end{abstract}

Kata Kunci: Pemanfaatan Media E-Learning, Kemandirian Belajar, Kreativitas Mahasiswa

\begin{abstract}
This study aims to determine the effect of the use of e-learning media and independent learning on student creativity in the Economics Faculty of Economics Financial Report analysis course, class of 20017, University of HKBP Nommensen, Academic Year 2020/2021. This research was conducted at the University of HKBP Nommensen Medan FKIP Economics. The results of this study indicate that the use of elearning in learning is very helpful for students / students to increase learning activities, honesty and having an independent personality. The phenomenon that occurs also illustrates that during the COVID-19 pandemic, students increase their learning independence. The use of e-learning media and independent learning has a positive effect on student creativity in the financial report analysis course for the economic education study program for the 2020/2021 academic year with the equation $Y=10.061+0.433 X 1+$ $0.461 X 2$.
\end{abstract}

Keywords: Utilization of E-Learning Media, Independent Learning, Student Creativity

\section{PENDAHULUAN}

Perkembangan ilmu pengetahuan dan teknologi saat ini sangat dibutuhkan dalam aspek kehidupan manusia salah satunya adalah pendidikan. Dengan bantuan teknologi informasi, proses belajar dan komunikasi antara siswa dengan guru sangat dipermudah, lebih efektif dan efisien. Salah satu teknologi informasi yaitu internet. Dengan adanya internet, sistem pembelajaran akan lebih mudah diakses oleh guru maupun peserta didik.

Pemanfaatan teknologi dalam situasi pandemic covid-19 memberikan perubahan terhadap sistem pembelajaran. Dalam dunia pendidikan saat ini, 
mulai banyak yang memanfaatkan teknologi informasi untuk menyampaikan suatu pembelajaran dengan istilah "e-learning". E-learning merupakan sistem pembelajaran elektronik atau e-pembelajaran (Electronic learning) yang disingkat dengan e-learning. Sistem e-learning merupakan implementasi pembelajaran yang memanfaatkan teknologi yang tidak terbatasi oleh ruang dan waktu sehingga e-learning juga dapat digunakan sebagai alternatif belajar. Sehubungan dengan itu, e-learning juga dapat digunakan apabila siswa berhalangan mengikuti pembelajaran secara tatap muka. Ini mengindikasikan bahwa e-learning juga sebagai pilihan bagi peserta didik.

Dengan kondisi yang demikian ini, mahasiswa dapat lebih memantapkan penguasaannya terhadap materi pembelajaran atau perkuliahan secara kreatif. Namun, pada kenyataannya kreativitas mahasiswa cenderung rendah. Hal ini dapat diketahui ketika dosen meminta mahasiswa untuk menyumbangkan ide dan kreativitas mahasiswa cenderung tidak dapat memberikannya. Selain pemanfaatan media e-learning, kemandirian juga sangat mempengaruhi kreativitas mahasiswa. Kemandirian belajar adalah aktivitas belajar yang didorong oleh kemauan sendiri tanpa dorongan dari orang lain, pilihan sendiri, dan tanggung jawab sendiri. Kemandirian belajar berarti peserta didik mampu mengikuti pelajaran dengan baik tanpa bergantung kepada orang lain untuk mengerjakan tugas atau penyelesaian masalah yang ada di dalam pembelajaran dan mendapatkan hasil yang sesuai dengan apa yang diinginkannya. Namun, pada kenyataannya mahasiswa cenderung kurang percaya diri terhadap hasil tugasnya sehingga lebih memilih mencontoh hasil kerja temannya. Mahasiswa juga masih belum dapat belajar mandiri dirumah tanpa bantuan dari dosen atau teman sekelasnya, hal ini dapat diketahui ketika mahasiswa cenderung terlambat dan tidak selesai mengerjakan tugas.

E-learning merupakan gabungan dari dua kata, yaitu e yang merupakan singkatan dari electronic (elektronik) dan learning (belajar). Secara terminologi, e-learning adalah sebuah proses pembelajaran yang dilakukan melalui network (jaringan komputer), biasanya lewat internet atau intranet. Jadi e-learning adalah belajar dengan menggunakan bantuan alat elektronik. Menurut Darmawan (2011:12) "e-learning pada hakikatnya adalah bentuk pembelajaran konvensional yang dituangkan dalam format digital dan disajikan melalui teknologi informasi".

Rusman (2011:265) "e-learning adalah segala aktivitas belajar yang menggunakan bantuan teknologi elektronik. Sehubungan dengan itu, $e$ learning juga dapat diaplikasikan dalam pendidikan konvensional dan pendidikan jarak jauh". E-learning memungkinkan siswa untuk belajar melalui komputer di tempat mereka masing masing, tanpa harus pergi mengikuti pelajaran dikelas. E-learning sering pula dipahami sebagai suatu bentuk pembelajaran berbasis web yang bisa diakses dari internet. Menurut Amri (2013:153) "e-learning merupakan kegiatan pembelajaran yang memanfaatkan jaringan (internet, $L A N, W A N$ ) sebagai metode penyampaian, interaksi, dan fasilitas serta didukung oleh berbagai bentuk layanan belajar lainnya". Nursalam (2008:135) mengungkapkan karakteristik e-learning yaitu "memanfaatkan jasa teknologi elektronik, memanfaatkan keunggulan 
komputer, menggunakan bahan ajar bersifat mandiri dan dapat diakses kapan dan dimana saja".

Menurut Rusman dkk (2011: 264) e-learning memiliki karakteristik, antara lain:

a. Interactivity (interaktivitas), tersedianya jalur komunikasi yang lebih banyak,

b. Independency (kemandirian), fleksibilitas dalam aspek penyediaan waktu, tempat, pengajar dan bahan ajar,

c. Accessibility (aksesibilitas), sumber-sumber belajar menjadi lebih mudah diakses, dan

d. Enrichment (pengayaan), kegiatan pembelajaran, presentasi materi kuliah dan materi pelatihan sebagai pengayaan.

Dari beberapa pendapat para ahli di atas dapat disimpulkan, bahwa $e$ learning memiliki beberapa karakter yaitu bersifat lebih individual atau mandiri, menggunakan koneksi internet, menggunakan elektronik, dan mudah untuk diakses dimana dan kapan saja.

Menurut Benny (2017:203-204) adapun pemanfaatan e-learning sebagai berikut:

1. Pemanfaatan e-learning sebagai sarana pembelajaran telah membuat proses belajar menjadi lebih individual dan dinamis.

2. Pengguna e-learning tidak hanya memilih dan mengetahui informasi, tetapi dapat mengirimkan kepada teman sejawat. Sehingga belajar lebih dinamis.

3. Pemanfaatan e-learning dapat juga membuat penggunanya menjadi lebih kreatif dalam melakukan proses belajar.

Menurut Mudlofir (2016:179) adapun kelebihan dan kekurangan $e$ learning:

Pembelajaran tidak dibatasi tempat dan waktu, peserta didik dalam proses pembelajaran ini harus aktif,menghemat biaya pendidikan, dan peserta didik terbiasa mandiri. Sedangkan kekurangannya, antara lain perlu penguasaan materi, memperhatikan pedagogic dari materi, peserta didik harus dimotivasi jika tidak akan gagal, dan kurangnya interaksi antara pendidik dengan peserta didik maupun antar peserta didik. Sedangkan menurut Rusman (2011:351-352) kelebihan dan kekurangan e-learning: Tersedianya fasilitas e-moderating, pembelajaran lebih fleksibel, interaksi pendidik dengan peserta didik lebih bebas akses, student centered,dan relatif lebih efisien. Sedangkan kekurangannya, antara lain kurangnya interaksi antar pendidik dengan peserta didik maupun antar peserta didik lainya, cenderung mengarah ke aspek pengetahuan, tidak semua tempat terakses internet, dan minimnya keterampilan pengoperasian komputer.

Suhendri dan Mardalena (2013:109) menyatakan bahwa: Kemandirian belajar adalah suatu aktivitas belajar yang dilakukan siswa tanpa bergantung kepada orang lain baik teman maupun gurunya dalam mencapai tujuan belajar yaitu menguasai materi atau pengetahuan dengan baik dengan kesadarannya sendiri siswa serta dapat mengaplikasikan pengetahuannya dalam menyelesaikan masalah dalam kehidupan.

Menurut Suciati (2016:9) kemandirian belajar "diartikan sebagai suatu bentuk yang terpusat pada kreasi peserta didik dari kesempatan dan pengalaman penting bagi peserta didik tersebut sehingga ia mampu percaya 
diri, memotivasi diri dan sanggup belajar setiap waktu". Dapat disimpulkan bahwa kemandirian belajar adalah kemampuan seseorang untuk melakukan aktivitas belajar dengan penuh keyakinan dan tanggung jawab, tidak tergantung kepada orang lain, berpikir alternatif dalam belajar, percaya diri, pentingnya belajar, dan memiliki tujuan jangka panjang atas tindakannya. Danuri (2010:15) mengemukakan bahwa ada beberapa ciri-ciri kemandirian belajar, yaitu: "adanya tendensi untuk berperilaku bebas dan berinisiatif, bersikap, dan berpendapat, adanya tendensi untuk percaya diri, adanya sifat original (keaslian) bukan meniru orang lain, dan adanya tendensi untuk mencoba diri". Adapun ciri-ciri kemandirian belajar, sebagaimana disampaikan oleh Warsita (2011:148) adalah "adanya inisiatif dan tanggung jawab dari peserta didik untuk proaktif mengelola proses kegiatan belajarnya".

Menurut Risfi dalam jurnal kemandirian pada usia lanjut (2019:154) kemandirian "merupakan kemampuan untuk mengendalikan dan mengatur pikiran, perasaan dan tindakan sendiri secara bebas serta berusaha sendiri untuk mengatasi perasaan malu dan keragu-raguan". Menurut Tasaik dan patma dalam jurnal peran guru dalam meningkatkan kemandirian belajar peserta didik kelas V SD inpres Samberpasi (2018:49) kemandirian adalah "suatu kondisi dimana seseorang memiliki hasrat bersaing untuk maju demi kebaikan dirinya sendiri, mampu mengambil keputusan dan inisiatif untuk mengatasi masalah yang dihadapi, memiliki kepercayaan diri dan melaksanakan tugas-tugasnya, serta bertanggung jawab atas apa yang dilakukan".

Menurut Basri (2008:53) kemandirian belajar siswa dipengaruhi oleh beberapa faktor, yaitu "faktor yang terdapat di dalam dirinya sendiri (factor endogen) dan faktor-faktor yang terdapat di luar dirinya (faktor eksogen)". Meece dan Schunk, dalam Aziz dan basry (2017:17) "faktor yang mempengaruhi kemandirian belajar siswa antara lain fasilitas sekolah, kurikulum, dan kompetensi guru yang mengajar dalam menunjang proses belajar".

Dari beberapa pendapat di atas, disimpulkan bahwa kemandirian belajar dipengaruhi oleh gen, sekolah, masyarakat. Oleh sebab itu, saat proses belajar mengajar di kelas, terjadi interaksi antara guru dengan siswa yang saling mempengaruhi satu sama lain, keadaan yang ditampilkan dalam situasi kelas maupun situasi di sekolah akan dipersepsikan tertentu dalam diri siswa, misalnya adanya situasi kelas yang semua siswanya aktif, cara mengajar guru, dan tingkat kemandirian siswa.

Menurut Rachmawati \& Kurniati $(2010 ; 14)$ kreativitas adalah: Kreativitas adalah kemampuan seseorang untuk melahirkan sesuatu yang baru, baik berupa gagasan maupun karya nyata yang relatif berbeda dengan apa yang telah ada. Selanjutnya ia menambahkan bahwa kreativitas merupakan kemampuan berpikir tingkat tinggi yang mengimplementasikan terjadinya eskalasi dalam kemampuan berpikir yang ditandai oleh suksesi, diskontinuitas, diferensiasi, dan integrasi antar tahap perkembangan.

Menurut Pardede dan Nainggolan (2017:50) "dosen perlu mendorong mahasiswa agar dapat berpikir lebih baik, misalnya pengajuan pertanyaan yang menantang sehingga meningkatkan rasa ingin tahu dan kreativitas mahasiswa". Menurut Sinaga (2016:359) menyatakan bahwa "kreativitas 
tidak akan berkembang jika anak dapat melakukan sesuatu dengan satu cara saja berilah kegiatan yang tidak berstruktur dalam struktur tertentu karena anak memerlukan batasan dan garis besar dalam mengerjakan suatu tugas, tetapi dalam batasan-batasan ini, hendaknya mereka dimungkinkan membuat pilihan". Menurut Mulyasa dalam Al-Khalili (2018:132) kreativitas terdiri dari empat tahap, yaitu:

a. Fase persiapan, yakni menyiapkan suatu kehidupan yang kreatif untuk dapat menghasilkan suatu kreasi.

b. Fase pengasuhan, yakni fase pertengahan antara kesiapan dan inspirasi untuk berpikir.

c. Fase inspirasi, fase ini diimplementasikan dengan munculnya solusi yang kreatif dengan cara spontan.

d. Fase realisasi, dalam fase ini diupayakan adanya penjelasan mengenai kebenaran apa yang direalisasikan.

Rachmawati dan Kurniati (2010:15) mengatakan bahwa "ciri-ciri kreativitas dapat dikelompokkan dalam dua kategori, kognitif, dan nonkognitif. Ciri kognitif antara lain orisinalitas, fleksibilitas, kelancaran, dan elaborasi. Sedangkan ciri non kognitif diantaranya motivasi sikap dan kepribadian kreatif".

\section{METODOLOGI PENELITIAN}

Penelitian ini merupakan penelitian kuantitatif. Penelitian ini bertujuan untuk mengetahui seberapa besar pengaruh pemanfaatan media $e$ learning terhadap kreativitas mahasiswa dan kemandirian belajar terhadap kreativitas mahasiswa. Populasi dalam penelitian ini adalah seluruh mahasiswa FKIP Ekonomi angkatan 2017 yang mengambil mata kuliah Analisa Laporan Keuangan di Universitas HKBP Nommensen Tahun Ajaran 2020/2021 yang berjumlah 50. Sampel dalam penelitian ini menggunakan teknik Total Sampling, karena jumlah populasi dibawah 100. Sesuai dengan pendapat Arikunto yaitu apabila populasi kurang dari 100, maka sampel dari keseluruhan populasi yang ada sehingga disebut penelitian populasi.

\section{HASIL PENELITIAN DAN PEMBAHASAN HASIL PENELITIAN}

Tabel 1. Sampel Mahasiswa Angkatan 2017 FKIP Ekonomi T.A 2020/2021

\begin{tabular}{|c|c|}
\hline Angkatan 2017 & Jumlah (Orang) \\
\hline Kelas A & 26 \\
\hline Kelas B & 24 \\
\hline Jumlah & 50 \\
\hline
\end{tabular}

Sebelum pengumpulan data dilakukan, terlebu dahulu dilakukan uji intrumen yaitu uji validitas dan uji reliabilitas. Berikut ini hasil uji validitas dan reliabilitas intrumen 
Tabel 2. Uji Validitas dan Uji Reliabilitas Pemanfaatan Media ELearning

\begin{tabular}{|c|c|c|c|}
\hline Item & R hitung & R tabel & Keterangan \\
\hline Item 1 & 0.998 & 0.6139 & Valid \\
\hline Item 2 & 0.998 & 0.6139 & Valid \\
\hline Item 3 & 0.998 & 0.6139 & Valid \\
\hline Item 4 & 0.998 & 0.6139 & Valid \\
\hline Item 5 & 0.998 & 0.6139 & Valid \\
\hline Item 6 & 0.998 & 0.6139 & Valid \\
\hline Item 7 & 0.998 & 0.6139 & Valid \\
\hline Item 8 & 0.998 & 0.6139 & Valid \\
\hline Item 9 & 0.998 & 0.6139 & Valid \\
\hline Item 10 & 0.998 & 0.6139 & Valid \\
\hline Item 11 & 0.998 & 0.6139 & Valid \\
\hline Item 12 & 0.998 & 0.6139 & Valid \\
\hline Item 13 & 0.998 & 0,6139 & Valid \\
\hline Item 14 & 0.998 & 0,6139 & Valid \\
\hline Item 15 & 0.998 & 0,6139 & Valid \\
\hline Item 16 & 0.835 & 0,6139 & Valid \\
\hline Item 17 & 0.998 & 0,6139 & Valid \\
\hline Item 18 & 0.998 & 0,6139 & Valid \\
\hline Item 19 & 0.835 & 0,6139 & Valid \\
\hline Item 20 & 0.998 & 0,6139 & Valid \\
\hline
\end{tabular}

\begin{tabular}{|c|c|}
\hline Cronbach's Alpha & N of Items \\
\hline 0.998 & 20 \\
\hline
\end{tabular}

Dari tabel di atas dapat disimpulkan bahwa instrumen Pemanfaatan Media E-Learning untuk 20 item adalah valid dimana $R_{\text {hitung }}>R_{\text {tabel }}$. Demikian juga uji reliabilitas didapatkan konstanta Cronbach's Alpha sebesar 0,998 lebih besar dari 0,6 artinya intrumen tersebut memiliki reliabilitas yang tinggi. Dengan demikian disimpulkan intrumen Pemanfaatan Media E-Learning ini sudah dapat digunakan.

Tabel 3. Uji Validitas Kemandirian Belajar

\begin{tabular}{|c|c|c|c|}
\hline Item & R hitung & R tabel & Keterangan \\
\hline Item 1 & 0.858 & 0.6139 & Valid \\
\hline Item 2 & 0.803 & 0.6139 & Valid \\
\hline Item 3 & 0.994 & 0.6139 & Valid \\
\hline Item 4 & 0.994 & 0.6139 & Valid \\
\hline Item 5 & 0.994 & 0.6139 & Valid \\
\hline Item 6 & 0.994 & 0.6139 & Valid \\
\hline Item 7 & 0.994 & 0.6139 & Valid \\
\hline Item 8 & 0.788 & 0.6139 & Valid \\
\hline Item 9 & 0.994 & 0.6139 & Valid \\
\hline Item 10 & 0.994 & 0.6139 & Valid \\
\hline
\end{tabular}




\begin{tabular}{|c|c|c|c|}
\hline Item 11 & 0.994 & 0.6139 & Valid \\
\hline Item 12 & 0.994 & 0.6139 & Valid \\
\hline Item 13 & 0.994 & 0,6139 & Valid \\
\hline Item 14 & 0.994 & 0,6139 & Valid \\
\hline Item 15 & 0.994 & 0,6139 & Valid \\
\hline Item 16 & 0.994 & 0,6139 & Valid \\
\hline Item 17 & 0.994 & 0,6139 & Valid \\
\hline Item 18 & 0.414 & 0,6139 & Tidak Valid \\
\hline Item 19 & 0.994 & 0,6139 & Valid \\
\hline Item 20 & 0.994 & 0,6139 & Valid \\
\hline
\end{tabular}

\begin{tabular}{|c|c|}
\hline Cronbach's Alpha & N of Items \\
\hline .0991 & 20 \\
\hline
\end{tabular}

Dari tabel di atas dapat disimpulkan bahwa intrumen Kemandirian Belajar untuk 20 item adalah 19 item valid dimana $R_{\text {hitung }}>R_{\text {tabel. }}$. Sehingga intrumen item 19 tidak digunkan Demikian juga uji reliabilitas didapatkan konstanta Cronbach's Alpha sebesar 0,991 lebih dari 0,6 artinya intrumen tersebut memiliki reliabilitas yang tinggi. Dengan demikian disimpulkan intrumen Kemandirian Belajar ini sudah dapat digunakan.

Tabel 4. Uji Validitas Kreativitas Mahasiswa

\begin{tabular}{|c|c|c|c|}
\hline Item & R hitung & R tabel & Keterangan \\
\hline Item 1 & 0.918 & 0,6139 & Valid \\
\hline Item 2 & 0.995 & 0,6139 & Valid \\
\hline Item 3 & 0.697 & 0,6139 & Valid \\
\hline Item 4 & 0.697 & 0,6139 & Valid \\
\hline Item 5 & 0.749 & 0,6139 & Valid \\
\hline Item 6 & 0.749 & 0,6139 & Valid \\
\hline Item 7 & 0.995 & 0,6139 & Valid \\
\hline Item 8 & 0.995 & 0,6139 & Valid \\
\hline Item 9 & 0.995 & 0,6139 & Valid \\
\hline Item 10 & 0.995 & 0,6139 & Valid \\
\hline Item 11 & 0.995 & 0,6139 & Valid \\
\hline Item 12 & 0.995 & 0,6139 & Valid \\
\hline Item 13 & 0.995 & 0,6139 & Valid \\
\hline Item 14 & 0.995 & 0,6139 & Valid \\
\hline Item 15 & 0.995 & 0,6139 & Valid \\
\hline Item 16 & 0.995 & 0,6139 & Valid \\
\hline Item 17 & 0.995 & 0,6139 & Valid \\
\hline Item 18 & 0.995 & 0,6139 & Valid \\
\hline Item 19 & 0.995 & 0,6139 & Valid \\
\hline Item 20 & 0.995 & 0,6139 & Valid \\
\hline
\end{tabular}

\begin{tabular}{|c|c|}
\hline Cronbach's Alpha & N of Items \\
\hline 0.993 & 20 \\
\hline
\end{tabular}

Dari tabel di atas dapat disimpulkan bahwa intrumen Kreativitas 
Mahasiswa untuk 20 item adalah valid dimana $R_{\text {hitung }}>R_{\text {tabel. }}$ Sehingga intrumen item 19 tidak digunkan Demikian juga uji reliabilitas didapatkan konstanta Cronbach's Alpha sebesar 0,993 lebih dari 0,6 artinya intrumen tersebut memiliki reliabilitas yang tinggi. Dengan demikian disimpulkan intrumen Kreativitas mahasiswa ini sudah dapat digunakan.

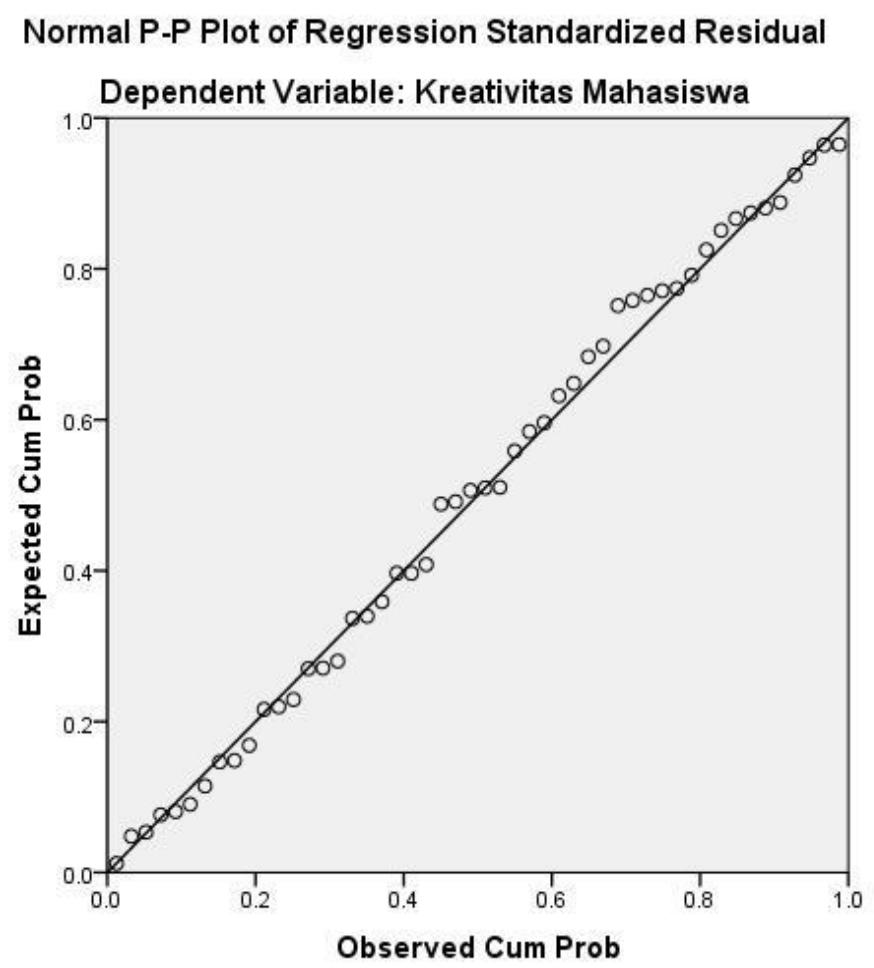

Gambar 1. Uji Normalitas

\section{Uji Linearitas}

a. Pemanfaatan Media E-Learning terhadap Kreativitas Mahasiswa

ANOVA Table

\begin{tabular}{|c|c|c|c|c|c|c|c|}
\hline & & & $\begin{array}{l}\text { Sum of } \\
\text { Squares }\end{array}$ & df & Mean Square & $\mathrm{F}$ & Sig. \\
\hline \multirow{5}{*}{$\begin{array}{l}\text { Kreativitas Mahasiswa * } \\
\text { Pemanfaatan Media E- } \\
\text { Leaning }\end{array}$} & \multirow[t]{3}{*}{ Between Groups } & (Combined) & 181.603 & 11 & 16.509 & 1.062 & .415 \\
\hline & & Linearity & 115.952 & 1 & 115.952 & 7.461 & .010 \\
\hline & & Deviation from Linearity & 65.650 & 10 & 6.565 & .422 & .927 \\
\hline & \multicolumn{2}{|l|}{ Within Groups } & 590.577 & 38 & 15.542 & & \\
\hline & \multicolumn{2}{|l|}{ Total } & 772.180 & 49 & & & \\
\hline
\end{tabular}

b. Kemandirian Belajar terhadap Kreativitas Mahasiswa

ANOVA Table

\begin{tabular}{|c|c|c|c|c|c|c|c|}
\hline & & & $\begin{array}{l}\text { Sum of } \\
\text { Squares }\end{array}$ & df & Mean Square & $F$ & Sig. \\
\hline \multirow{5}{*}{$\begin{array}{l}\text { Kreativitas Mahasiswa * } \\
\text { Kemandirian Belajar }\end{array}$} & \multirow[t]{3}{*}{ Between Groups } & (Combined) & 182.794 & 10 & 18.279 & 1.210 & .315 \\
\hline & & Linearity & 101.658 & 1 & 101.658 & 6.727 & .013 \\
\hline & & Deviation from Linearity & 81.136 & 9 & 9.015 & .597 & .792 \\
\hline & \multicolumn{2}{|l|}{ Within Groups } & 589.386 & 39 & 15.112 & & \\
\hline & \multicolumn{2}{|l|}{ Total } & 772.180 & 49 & & & \\
\hline
\end{tabular}


Coefficients $^{\mathrm{a}}$

\begin{tabular}{|c|c|c|c|c|c|c|c|c|}
\hline \multirow[b]{2}{*}{ Model } & & \multicolumn{2}{|c|}{ Unstandardized Coefficients } & \multirow{2}{*}{$\begin{array}{c}\begin{array}{c}\text { Standardized } \\
\text { Coefficients }\end{array} \\
\text { Beta }\end{array}$} & \multirow[b]{2}{*}{$t$} & \multirow[b]{2}{*}{ Sig. } & \multicolumn{2}{|c|}{ Collinearity Statistics } \\
\hline & & $B$ & Std. Error & & & & Tolerance & VIF \\
\hline \multirow[t]{3}{*}{1} & (Constant) & 10.062 & 16.794 & & .599 & .552 & & \\
\hline & $\begin{array}{l}\text { Pemanfaatan Media E- } \\
\text { Leaning }\end{array}$ & .433 & .181 & .317 & 2.391 & .021 & .938 & 1.066 \\
\hline & Kemandirian Belajar & .461 & .215 & .284 & 2.143 & .037 & .938 & 1.066 \\
\hline
\end{tabular}

a. Dependent Variable: Kreativitas Mahasiswa

Dilihat dari hari VIF pada tabel diatas bahwa perolehan nilai VIF untuk kedua variable diatas adalah 1,066. Nilai VIF yang diperoleh adalah lebih kecil dari 10, artinya antar variable X (Pemanfaatan Media E-Learning dan Kemandirian Belajar) tidak terjadi Multikolinieritas.

\section{Uji Regresi Liniear Berganda}

\begin{tabular}{|c|c|c|c|c|c|c|c|c|}
\hline \multicolumn{9}{|c|}{ Coefficients $\mathrm{s}^{\mathrm{a}}$} \\
\hline \multirow[b]{2}{*}{ Model } & & \multicolumn{2}{|c|}{ Unstandardized Coefficients } & \multirow{2}{*}{$\begin{array}{c}\begin{array}{c}\text { Standardized } \\
\text { Coefficients }\end{array} \\
\text { Beta }\end{array}$} & \multirow[b]{2}{*}{$t$} & \multirow[b]{2}{*}{ Sig. } & \multicolumn{2}{|c|}{ Collinearity Statistics } \\
\hline & & $B$ & Std. Error & & & & Tolerance & VIF \\
\hline \multirow[t]{3}{*}{1} & (Constant) & 10.062 & 16.794 & & .599 & .552 & & \\
\hline & $\begin{array}{l}\text { Pemanfaatan Media E- } \\
\text { Leaning }\end{array}$ & .433 & .181 & .317 & 2.391 & .021 & .938 & 1.066 \\
\hline & Kemandirian Belajar & .461 & .215 & .284 & 2.143 & .037 & .938 & 1.066 \\
\hline
\end{tabular}

a. Dependent Variable: Kreativitas Mahasiswa

\section{Uji Parsial (Uji t)}

\begin{tabular}{|c|c|c|c|c|c|c|c|c|}
\hline \multicolumn{9}{|c|}{ Coefficients $^{a}$} \\
\hline \multirow{2}{*}{\multicolumn{2}{|c|}{ Model }} & \multicolumn{2}{|c|}{ Unstandardized Coefficients } & \multirow{2}{*}{$\begin{array}{c}\begin{array}{c}\text { Standardized } \\
\text { Coefficients }\end{array} \\
\text { Beta }\end{array}$} & \multirow[b]{2}{*}{$t$} & \multirow[b]{2}{*}{ Sig. } & \multicolumn{2}{|c|}{ Collinearity Statistics } \\
\hline & & $\mathrm{B}$ & Std. Error & & & & Tolerance & VIF \\
\hline \multirow[t]{3}{*}{1} & (Constant) & 10.062 & 16.794 & & .599 & .552 & & \\
\hline & $\begin{array}{l}\text { Pemanfaatan Media E- } \\
\text { Leaning }\end{array}$ & .433 & .181 & .317 & 2.391 & .021 & .938 & 1.066 \\
\hline & Kemandirian Belajar & .461 & .215 & .284 & 2.143 & .037 & .938 & 1.066 \\
\hline
\end{tabular}

a. Dependent Variable: Kreativitas Mahasiswa

Uji Simultan (Uji f)

ANOVA $^{\text {a }}$

\begin{tabular}{|ll|r|r|r|r|l|}
\hline Model & & \multicolumn{1}{c|}{$\begin{array}{c}\text { Sum of } \\
\text { Squares }\end{array}$} & df & Mean Square & F & Sig. \\
\hline 1 & Regression & 174.356 & 2 & 87.178 & 6.854 & $.002^{\mathrm{b}}$ \\
& Residual & 597.824 & 47 & 12.720 & & \\
& Total & 772.180 & 49 & & & \\
\hline
\end{tabular}

a. Dependent Variable: Kreativitas Mahasiswa

b. Predictors: (Constant), Kemandirian Belajar, Pemanfaatan Media E-Leaning

Dari hasil Tabel Anova diatas diperoleh bahwa nilai F $(6,854)$ dengan signifikansi sebesar 0,002. Artinya, secara simultan variable emanfaatan 
media e-learning (X1) dan Kemandirian Belajar (X2) berpengaruh terhadap kreativitas belajar Mahasiswa pada mata kuliah analisa laporan keuangan.

\section{Koefisien Determinasi $\left(\mathbf{R}^{2}\right)$}

Model Summary ${ }^{\mathbf{b}}$
\begin{tabular}{|c|l|l|l|l|}
\hline Model & $\mathbf{R}$ & R Square & $\begin{array}{l}\text { Adjusted R } \\
\text { Square }\end{array}$ & $\begin{array}{l}\text { Std. Error of the } \\
\text { Estimate }\end{array}$ \\
\hline $\mathbf{1}$ & $\mathbf{. 7 5 0}^{\mathrm{a}}$ & $\mathbf{. 5 6 2}$ & & $\mathbf{3 . 1 8 5}$ \\
\hline
\end{tabular}

a. Predictors: (Constant), Kemandirian Bel, E-Learning
b. Dependent Variabel: Kreativitas

\section{PEMBAHASAN}

Hasil penelitian menunjukkan pemanfaatan media e-learning dengan kreativitas mahasiswa pada mata kuliah analisa laporan keuangan, variabel $X_{1}$ dengan variabel $Y$ dapat dilihat nilai $t_{\text {hitung }}>t_{\text {tabel }}(2,391>2,012)$ dengan nilai signifikansi $0,02<0,05$. Artinya bahwa Ada pengaruh antara pemanfaatan media e-learning dengan kreativitas mahasiswa pada mata kuliah analisa laporan keuangan, variabel $\mathrm{X}_{1}$ dengan variabel $\mathrm{Y}$ dapat dilihat nilai $t_{\text {hitung }}>t_{\text {tabel }}(2,391>2,012)$ dengan nilai signifikansi $0,02<0,05$.

Sementara antara kemadirian belajar dengan kreativitas mahasiswa pada mata kuliah analisa laporan keuangan secara parsial, yaitu variabel $\mathrm{X}_{2}$ dengan variabel $Y$ dapat dilihat nilai $t_{\text {hitung }}>t_{\text {tabel }}$ sebesar $(2,143>2,012)$ dengan nilai signifikansi $0,03<0,05$. Artinya ada pengaruh yang siqnifikan antara kemadirian belajar dengan kreativitas mahasiswa pada mata kuliah analisa laporan keuangan. Dan antara pemanfaatan media e-learning dan kemandirian belajar terhadap kreativitas mahasiswa pada mata kuliah analisa laporan keuangan dengan koefisien $r^{2}=0,562$ dan rumus regresi gandanya $\mathrm{Y}=10,061+0,433 \mathrm{X}_{1}+0,461 \mathrm{X}_{2}$.

Dengan demikian kreativitas mahasiswa pada mata kuliah analisa laporan keuangan meningkat dapat dipengaruhi oleh pemanfaatan media $e$ learning dan kemandirian belajar sebesar $56,2 \%$, selebihnya dijelaskan dari faktor lain yang tidak dibahas dalam penelitian ini.

\section{KESIMPULAN}

1. Ada pengaruh antara pemanfaatan media e-learning dengan kreativitas mahasiswa pada mata kuliah analisa laporan keuangan, variabel $\mathrm{X}_{1}$ dengan variabel $\mathrm{Y}$ dapat dilihat nilai $\mathrm{t}_{\text {hitung }}>\mathrm{t}_{\text {tabel }}(2,391>2,012)$ dengan nilai signifikansi $0,02<0,05$.

2. Ada pengaruh antara kemadirian belajar dengan kreativitas mahasiswa pada mata kuliah analisa laporan keuangan, variabel $X_{2}$ dengan variabel $\mathrm{Y}$ dapat dilihat nilai $\mathrm{t}_{\text {hitung }}>\mathrm{t}_{\text {tabel }}$ sebesar $(2,143>2,012)$ dengan nilai signifikansi $0,03<0,05$.

3. Ada pengaruh antara pemanfaatan media e-learning dan kemandirian belajar terhadap kreativitas mahasiswa pada mata kuliah analisa laporan keuangan dengan koefisien $r^{2}=0,562$ dan rumus regresi gandanya $\mathrm{Y}=$ $10,061+0,433 X_{1}+0,461 X_{2}$. Dengan demikian kreativitas mahasiswa pada mata kuliah analisa laporan keuangan meningkat dapat dipengaruhi oleh pemanfaatan media e-learning dan kemandirian 
belajar sebesar 56,2\%, selebihnya dijelaskan dari faktor lain yang tidak dibahas dalam penelitian ini.

\section{SARAN}

1. Diharapkan pada peneliti selanjutnya dapat menambahkan variabelvariabel lain yang dapat mempengaruhi kreativitas mahasiswa yang tidak di teliti dalam penelitian ini.

2. Diharapkan pada peneliti selanjutnya dapat menambahkan jumlah sampel dan jumlah indikator yang di anggap penting pada setiap variabel yang digunakan. Hal ini bertujuan agar dapat meningkatkan keakuratan data.

\section{DAFTAR PUSTAKA}

Abdussalam, A. (2018). Mengembangkan Kreativitas Anak. Jakarta: Pustaka Al-kautsar.

Amri, S. (2013). Pengembangan dan Model Pembelajaran dalam Kurikulum 2013. Jakarta: PT Prestasi Pustakaraya.

Basri, H. (2008). Landasan Pendidikan. Bandung: Pustaka Setia.

Danuri. (2010). Kemandirian Belajar. Bandung: Sinar Baru.

Darmawan, D. (2011). Teknologi Pembelajaran. Bandung: PT Remaja Rosdakarya.

Mudlofir, A. (2016). Desain Pembelajaran Inovatif. Jakarta: PT RajaGrafindo Persada.

Nursalam. (2008). Pendidikan Dalam Keperawatan. Jakarta: Salemba Medika.

Pardede dan Nainggolan. (2017). Penerapan Strategi Quantum Teaching Berbantuan Media Multisim untuk Menumbuhkan Kebiasaan positif Mahasiswa agar Terlibat Aktif dalam Pembelajaran Elektronika Dasar-2. Jurnal Ilmiah Kohesi. 46-57.

Pribadi, B. (2017). Media dan Teknologi dalam Pembelajaran. Jakarta: PT Balebat Dedikasi Prima.

Rachmawati, Y. (2010). Strategi Pengembangan Kreativitas Pada Anak Usia Taman Kanak-Kanak. Jakarta: Kencana Prenada Media Group.

Risfi, S. (2019). Kemandirian Pada Usia Lanjut. Jurnal Psikologi Islam AlQalb, 152-165.

Rusman. (2010). Model-Model Pembelajaran. Jakarta: PT RajaGrafindo Persada.

Rusman,dkk. (2011). Pembelajaran Berbasis Teknologi Informasi dan Komunikasi. Jakarta: PT RajaGrafindo Persada.

Sinaga, D. (2016). Penerapan Student Teams Achievement Division untuk Meningkatkan Hasil Belajar dan Kreativitas Belajar Ekonomi. Jurnal Cakrawala Pendidikan. 357-364.

Suciati, W. (2016). Kiat Sukses Melalui Kecerdasan Emosional dan Kemandirian Belajar. Bandung: CV Rasi Terbit.

Tasaik, H. L. (2018). Peran Guru Dalam Meningkatkan Kemandirian Belajar Peserta Didik Kelas V SD Inpres Samberpasi. Metodik Didaktik, Vol.14, 45-55. 
Warsita, B. (2011). Teknologi Pembelajaran dan Aplikasinya. Jakarta: Rineka Cipta. 